\section{The Royal Colleges, the LDS and the struggles of the dental profession}

\author{
S. Gelbier ${ }^{1}$
}

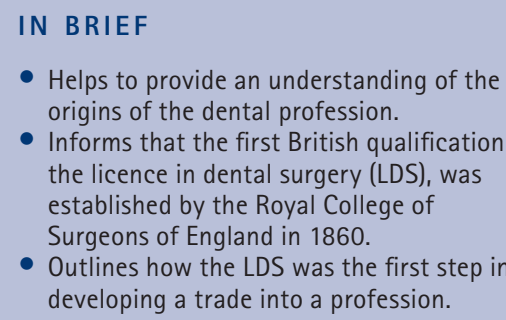

This paper is based on a lecture to the symposium on 'apprenticeship to life long learning: dental education through the centuries', Centre for the History of Medicine, University of Glasgow.

\section{INTRODUCTION}

This paper examines the licence in dental surgery (LDS), the first United Kingdom dental qualification, and the part played in its development by the Royal Surgical Colleges.

When I gained my LDS from the English college in October 1961, a large percentage of dentists had an LDS from one of the surgical colleges: England (36.28\%), Glasgow (7.31\%), Edinburgh (6.84\%) and Ireland (1.70\%). Other LDSs were awarded by the universities but by then the BDS was overtaking the LDS.

\section{DENTISTRY IN THE 18TH AND 19TH CENTURY}

Two important questions are: when did the LDS start and why? The dental profession and its origins are fascinating from both sociological and technological standpoints. Although dentistry is now a highly regarded profession it has not always been so. In the mid 19th century in the UK a variety of people practised dentistry, mainly tooth extractions. Tales of malpractice abounded. Some with surgical or medical diplomas practised dentistry as an appendage to their main profession. Apothecaries prescribed cures directly to patients. Chemists and druggists combined their practices with dentistry. Blacksmiths and farriers could make extraction forceps

\footnotetext{
'Unit for the History of Dentistry, KCL Dental Institute, Floor 18, Dental Tower, Guy's Hospital, St Thomas' Street, London, SE1 9RT

Correspondence to: Professor Stanley Gelbier Email:sgelbier@yahoo.co.uk
}

\section{Refereed Paper}

Accepted 12 April 2012

DOI: $10.1038 /$ sj.bdj.2012.775

${ }^{\circledR}$ British Dental Journal 2012; 213: 237-241 and sometimes used them to take out teeth. Some goldsmiths, silversmiths and makers of surgical appliances gave technical help to surgical-dentists and later set up on their own to provide dental treatment. In a Thomas Rowlandson's 18th century sketch, Barnaby Factotum made wigs and sausages and also drew teeth (Fig 1).

Charlatans or quacks had little expertise, picking up the tricks of the trade as they went along. They often worked at street markets and fairs, extracting teeth and applying medicaments to the gums as a lucrative sideline. Their arrival was often heralded by trumpeters. To inspire confidence an accomplice with a very loose tooth was often the first patient. Otherwise the quack hid an already-extracted tooth in his palm. The operator sometimes rubbed the gum with his secret balm before applying the extraction instrument. When a genuine sufferer mounted the rostrum a bugler or drummer sometimes played loudly to drown the patient's screams. In the early part of the century, with no local or general anaesthetics, we cannot begin to imagine what it was like for patients. But for the crowd, it was free entertainment.

Rich people went to surgeons practising dentistry, especially in London and some other large towns. Others sought care from dentists trained through five-year apprenticeships. Established practices sometimes were passed from father to son, each generation training the next.

\section{DEVELOPMENTS IN SURGERY IN LONDON}

Surgeons were important, but how exactly were they defined and which colleges did

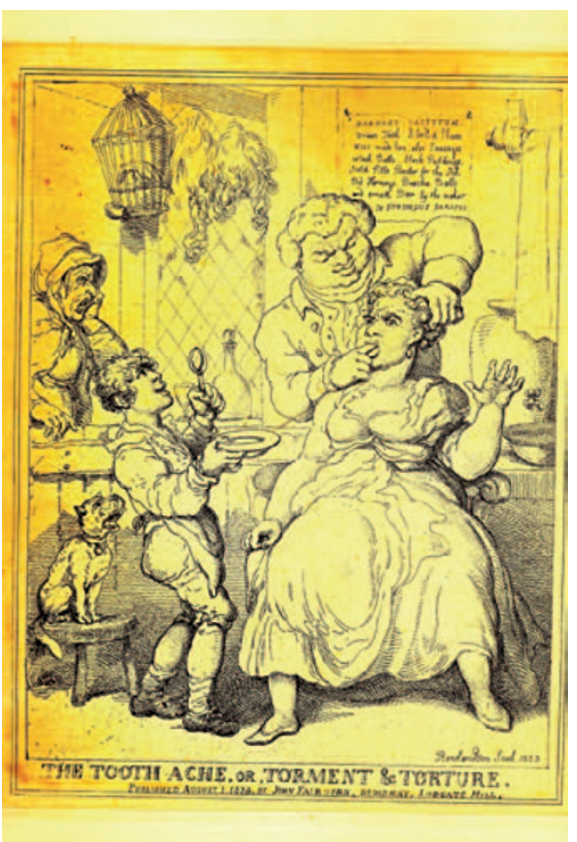

Fig 1 Portrait, 'The tooth ache or torment and torture', Thomas Rowlandson, 1823

they offer their allegiance? Before dentistry could advance there needed to be organised surgery. In London, a series or mergers and dissolutions saw surgeons and barbers join and then separate: 1300, Company of Barbers of London; 1369, Fellowship of Surgeons; 1462, Incorporated by Royal Charter; and 1536-1539, Guild of Surgeons (especially ex-monks released by dissolution of the monasteries who practised minor surgery). In 1540, King Henry VIII awarded a charter to the new livery Company of Barber-Surgeons of London. ${ }^{1}$ Although formally joined, there was still a divide, with two classes of members. The rules of the company said no surgeons could practise barbery and no barbers could practise surgery. In 1745, the union split into the 
Worshipful Company of Barbers of City of London and the Company of Surgeons of London. In 1800, the Company of Surgeons became the Royal College of Surgeons of London, extended in 1843 to cover the whole of England. But what about the rest of Britain?

\section{SURGERY AWAY FROM LONDON}

In 1599, King James VI awarded a royal charter to the Glasgow Faculty of Physicians and Surgeons, which was founded by Peter Lowe. Originally a regulatory authority to ensure surgeons and physicians were well trained, at first it included barbers and apothecaries but by 1722 they were excluded. In 1909, it became a royal faculty, re-named again in 1962 as a royal college.

In 1505 , a charter of privileges was granted to its barber-surgeons by the Town Council of Edinburgh. Among the many important duties of this Craft Guild of Edinburgh, it had to ensure all apprentices were literate, that every master had a full knowledge of anatomy and surgical procedures, and that this knowledge was tested at the end of apprenticeship. In the following year it received a royal charter from King James IV of Scotland. A 1778 charter from King George III incorporated the surgeons as the Royal College of Surgeons of the City of Edinburgh. Queen Victoria's 1851 charter separated the college from the Town Council.

Following on from an earlier Guild of Barber Surgeons, in 1784, the Royal College of Surgeons in Ireland was granted a charter which gave it power to control the practice of surgery and to make provision for surgical education. The founding fathers were very influenced by the standard of surgery in France at that time. As a result they adopted a French motto, 'consilio manuque', meaning scholarship and dexterity. The stimulus for growth in the early years was the demand for army and navy surgeons for the Napoleonic wars. An 1844 charter from Queen Victoria instituted a fellowship, which could only be obtained by examination taken at least three years after initial qualification.

So in one way or another, the whole of Britain had a base for maintaining standards in surgery. But how did dental surgery, fit in?
Establishment of the dental
profession in Victorian times

The science and practice of dentistry developed rapidly in an age of scientific discovery, technological advances and developments in education, helping it towards professionalisation. The industrial revolution made money and skills available for the development of better equipment and materials, and enabled more people to pay for sophisticated care. An increased demand for treatment encouraged more people to practise dentistry fulltime. In the 19th century a structure began to evolve for practitioners. ${ }^{2}$

From the mid-1840s, some dentists agitated for advancement. At that time there was no profession or formal teaching and practitioners tended not to pass on the benefits of their knowledge or experience. Alfred Hill, a dentist-observer of the period, summed it up as an era when everyone was only interested in himself: ${ }^{3}$ '[w]ithout a common centre or bond of union, the dentists of that time practised exclusively and primarily for their own interests.'

Major advances don’t just happen. They require passionate individuals to press their cause. And so it was with dentistry. In 1841, George Derby Waite MRCS, an eminent surgeon-dentist, sent an 'appeal' to Parliament. ${ }^{4}$ He said anyone, even if illiterate, could practise dentistry and thus society was not protected. He produced the same information for the public in a pamphlet. 'It seems extraordinary that in this great capital and in this day of advanced science, such charlatanism should not directly be checked.' Waite said it was astonishing that the most enlightened city in Europe still allowed charlatans to practise dentistry.

Hill thought British dentists who "were slumbering, or at any rate inactive' ${ }^{3}$ could learn a lot from America where the world's first dental school, Baltimore College of Dental Surgery, had opened its doors in 1840. Totally independent of surgeons, it awarded a Doctorate of Dental Surgery degree. So from these beginnings, American dentists were called doctors.

By the mid-1850s UK practitioners were divided into two groups. The smaller one consisted mainly of better-educated surgeons who practised dentistry in London and other large cities and thought dentistry should be a branch of surgery. The much larger, non-surgeon, group, felt it should be independent, as in the USA.

In August 1855, a letter from Samuel Lee Rymer appeared in the Lancet to promote the need for a college of dental surgery. ${ }^{5}$ As a result, meetings were held at the London Tavern in Bishopsgate. They wanted dentists to become part of a college without first undertaking surgical training and qualification.

However, a group of eminent Londonbased surgeon-dentists led by John Tomes, Samuel Cartwright junior and James Salter had already met in November and December 1855. As a result, they sent a memorial or petition to the Royal College of Surgeons of England asking it to institute an examination and department of dental surgery. Interestingly, Tomes was not at that time even a member of the Royal College. These 'memorialists' kept their machinations secret for a year. They were only disclosed in October 1856, when the other group held its meetings. There was immediately uproar in the profession. Even some members of the surgical college were annoyed at not being consulted.

The memorialists did not get an immediate response from the College of Surgeons. In 1856, under the influence of Tomes, they formed the academic Odontological Society of London. While fighting for the Royal College to award a dental diploma, they realised the need to train future dentists. In 1858 they established the Dental Hospital of London, at 32 Soho Square, where its London School of Dental Surgery opened in the following year, nearly 20 years behind America's Baltimore College.

The Dental Hospital of London was not the first dental establishment in the city. The London Institution for Diseases of the Teeth was founded in 1839 (until 1845) in Great Windmill Street by three leading practitioners, E. Saunders, J. Snell and W. A. Harrison. using their own money. ${ }^{6}$ The London Dental Dispensary followed in 1856 founded by C. J. Fox in Regents Park. Both were mainly intended to treat poor people, but they were also attended by pupils learning their trade.

However, the Dental Hospital of London was the first UK institute to be established specifically as a 'teaching' hospital to instruct future dentists. It was: '[f]ounded 
for purpose of affording to the poor generally the means of obtaining gratuitous relief and advice, in such cases as are included in the special practice of Dental Surgery; and also for affording an opportunity of instruction to those who enter the Dental Profession. ${ }^{7}$ The hospital was remarkably successful, not least because as a charity much of its work was focused on helping the poor, hitherto largely unable to afford the high cost of dental surgery. Its reputation was such that even Florence Nightingale requested an appointment, having broken four of her teeth. Under the patronage of King Edward VII it became the Royal Dental Hospital in October 1901.

Meanwhile, the many people who preferred the profession to develop without the influence of surgeons, formed the College of Dentists of England, with its own training programme and membership (MCDE) qualification. Their Metropolitan School of Dental Science opened four days after the Dental Hospital of London commenced its activities. But it but failed to make adequate arrangements for the students to obtain clinical experience until three years later, when the National Dental Hospital opened in 1861 in London's Tottenham Court Road. ${ }^{8}$ A little experience was gained at the Westminster Dispensary in Soho.

Unsurprisingly, tensions grew between the two groups. The Odontologicals kept up the pressure on the Royal College of Surgeons. Its officials said it would like to help, but was not allowed by its charter to do so.

At the same time, John Smith tried to get the Royal College of Surgeons of Edinburgh to introduce a dental diploma, but he also failed. Instead he concentrated on the establishment of a dental hospital and school.

\section{SOME BACKGROUND TO THE BATTLES}

It seemed like a rebuttal. However, we must remember that life for the 1850s surgeons was not easy: there was a turf war between them, the physicians and apothecaries. Physicians were well educated, often at expensive Oxford or Cambridge colleges. They generally treated rich patients by talking to them, but usually without examining them. They looked down on the surgeons, many of whom were poorly educated and often trained by apprenticeships or sometimes on the battlefield. Apothecaries arose out of spicers and pepperers, ie they were traders. Even the surgeons looked down on them. Some apothecaries provided herbs and medicines for poor people, copying what physicians had asked them to provide for their rich patients. Slowly many became general practitioners for poor people. Neither the physicians nor surgeons liked it, so there were continual battles and law suits.

Perhaps these battles explain why the surgeons were not fully receptive to the dentists' aspirations. Following several attempts to unite these three groups into a single medical profession success came with passage of the great 1858 Medical Act.

As pointed out by Bishop and Parker, ${ }^{9}$ Tomes's membership of the Royal Society was crucial to success. He did not have a Royal College of Surgeons qualification so could not work from within the college. However, he did have friends who were members, including Septimus Sibley, his brother-in-law and fellow Middlesex Hospital man, who was elected a fellow of the college in 1857. Tomes used his Royal Society contacts, including the surgical college's secretary, Edward Belfour. He suggested Tomes and his colleagues should petition parliament to get a clause inserted into the forthcoming Medical Bill.

In February 1857, Tomes informed the council of the Odontological Society that a Medical Practitioners Bill to regulate the medical profession was coming before Parliament. They agreed to again petition the English surgical college. Several leading dentists, especially Tomes, encouraged their patients who were members of parliament, to act on this suggestion. On 6 July 1858 , at the committee stage of the Bill, one such patient, A. J. Beresford Hope MP, moved an amendment to allow the college to examine dentists to test their fitness to practise and to grant them a certificate if it was satisfied. Parliament agreed unanimously.

The Bill gained royal assent on 2 August, to become the first Medical Act. Clause 48 of the Act led to the granting of a new charter for the Royal College of Surgeons on 8 September 1859. It gave the college formal power to examine candidates and award certificates of fitness to practise

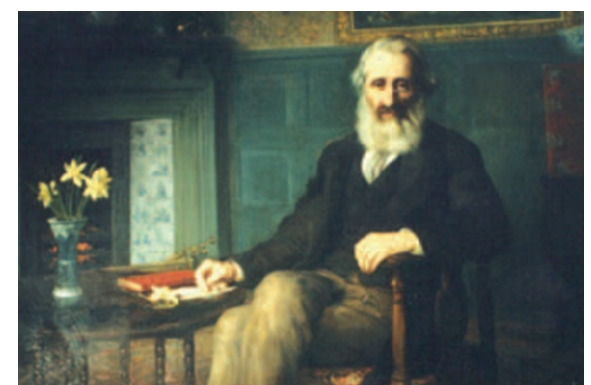

Fig. 2 John Tomes MRCS

dental surgery. So for the first time dentistry and a dental qualification were formally recognised, a major step along the path from a trade to a profession. The efforts of John Tomes, Edwin Saunders, Samuel Cartwright junior and their colleagues were vindicated.

When news of this impending advance came, George Waite and five colleagues submitted a plea for a royal charter of incorporation of the opposition, the College of Dentists of England, with recognition of its diploma. Although many town and country practitioners supported them, they failed. They realised the game was up when they learned that over 40 candidates, including some distinguished members of the profession, had submitted entries for the examination. Originally due to be held only on 13 March 1860, two further days had to be allocated for the exam.

In 1859 John Tomes (Fig. 2) was awarded the MRCS of the English college, which gave him a formal relationship.

\section{THE LDS EXAMINATION}

Tomes plus Arnold Rogers and Thomas Bell were appointed by the Council of the Royal College as the first examiners for the dental component of the Licence in Dental Surgery. ${ }^{10}$ They were joined by Montcrieff Arnott, William Lawrence and Joseph Henry Green as the first surgical examiners.

The board first met on 1 March 1860 with Lawrence in the chair. It decided that candidates would be required to provide evidence that they had commenced their dental education before September 1859. Secondly they had to produce a certificate of 'moral and professional character' ${ }^{10}$ signed by two members of the college - ie surgeons. In an interesting move Bell, Tomes and Rogers then tabled the required certificates and declared themselves as candidates. 
On 8 March they considered 26 submitted certificates, including some from outside London. Among them was one from Edwin Saunders, one of the fighters for the LDS. For some reason he withdrew his application and never took the exam. Perhaps he felt it was enough that he already had an FRCS and was Queen Victoria's dental practitioner (he was knighted in 1883). By 13 March the board had received letters from a number of other people withdrawing their entries.

The board sought a legal opinion as to whether it must admit to the exam candidates who sent in the required certificates but who were in the habit of advertising what the board called 'a peculiar line of practice', ${ }^{11}$ or acting otherwise in an unprofessional manner. ${ }^{12}$ The board was advised that every person who complied with the orders and regulations was entitled to be examined.

In spite of this legal advice, on 12 July the board informed Edmund Durant it had unquestionable evidence that he carried on the business of a pharmaceutical chemist in conjunction with his brother Frederic. So it declined to admit him to the exam. As a result of this kind of refusal, in 1910 a group of chemists tried to get parliament to amend another Bill going through the House, to make it possible for the Worshipful Company of Apothecaries to examine Chemist-Dentists in dentistry, ${ }^{13}$ but they failed.

The Dental Board also declined to admit George Lyddon, as he advertised in the Hampshire Telegraph and Sussex Chronicle. And J. Robertson of Bath was not allowed because he was in practice as a dentist with his father who, in their opinion, was in the practice of advertising his mode of practice in an unprofessional manner. It is clear that from the beginning they regarded ethics as important.

\section{THE FIRST EXAMINATIONS}

The first examinations took place in 1860 (see Fig. 3).

The first 15 practitioners were awarded the LDS after taking their examinations on 13 March and paying a fee of 10 guineas (Fig. 4). By the end of March there were 43 successes. On 11 April there was only one candidate: Henry Andrew Dewar of Aberdeen had to pay an additional fee of 5 guineas for a special meeting of the exam board. Figure 4 shows those people who gained the LDS on the first day.

It is interesting that the three examiners head the list. There is evidence that they paid their entry fees but one wonders how they were examined. All candidates were from London. Many became famous in various branches of dentistry.

The 1858 Medical Act also established the General Council of Medical Education and Registration of the United Kingdom, which came to be known as the General Medical Council. It instructed the GMC to maintain a register of medical practitioners; but to their annoyance, dentists were excluded. ${ }^{2}$

\section{THE FATE OF THE DENTAL SOCIETIES}

The College of Dentists realised it no longer had a purpose. Therefore, Thomas Underwood of the College of Dentists and John Tomes representing the Odontological Society met to discuss the future. As a result the two societies merged in 1863 to form the Odontological Society of Great Britain. Samuel Cartwright senior was its first president.

The President's son, also Samuel, was one of those who fought for the LDS and who gained it on the very first day. In the same year, Samuel Cartwright junior (Fig. 5) was appointed as the first UK Professor of Dental Surgery at King's College London, which didn't even have a dental school at that time!

The London-based Odontological Society became an important focus for dental science and learning through its meetings. It published transactions but remained aloof from dental politics. In 1907, it joined fourteen other medical and surgical societies to become the Section of Odontology of the Royal Society of Medicine.

Similar societies grew up elsewhere, pressing for further qualifications. They succeeded after passage of the 1878 Dentists Act. The three other UK royal surgical colleges then instituted their own LDS in 1879.

\section{WOMEN AND THE LDS}

There was still one fight left for the London LDS. Men continued to be prejudiced against women practising as qualified surgeons or dentists. Yet that was to be expected; it reflected women's place

\begin{tabular}{|l|l|}
\hline Date & No. candidates \\
\hline 13 March & 15 \\
\hline 14 March & 14 \\
\hline 20 March & 14 \\
\hline Total March & 43 \\
\hline 2 April & 19 \\
\hline 11 April & 1 \\
\hline 2 May & 13 \\
\hline 13 June & 12 \\
\hline
\end{tabular}

Fig. 3 The first LDS examinations, 1860

\begin{tabular}{l|l}
\hline Name & Location \\
\hline Thomas Bell & New Broad St \\
\hline John Tomes & Cavendish Sq \\
\hline Arnold Rogers & Hanover Sq \\
\hline John Herring Parkinson & Sackville St \\
\hline Samuel Cartwright Jnr & Old Burlington St \\
\hline James Parkinson & King St, St James' \\
\hline Thomas Arnold Rogers & Hanover Sq \\
\hline Wm Anthony Harrison & Keppel St \\
\hline Henry Rogers & Hanover Sq \\
\hline Alfred George Canton & Gt Marlborough St \\
\hline John Bowman Fletcher & New Burlington St \\
\hline Edwin Sercombe & Brook St \\
\hline John Rigden Mummery & Cavendish Sq \\
\hline George Augustus Ibbetson & Brook St \\
\hline Wm Alfred Newman Cattlin & Highbury Place \\
\hline
\end{tabular}

Fig. 4 The successful candidates on 13 March 1860

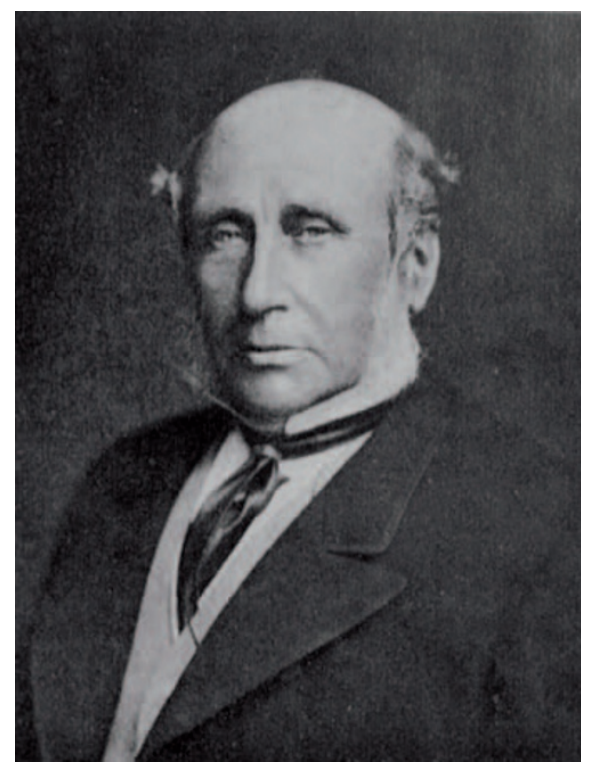

Fig. 5 Samuel Cartwright junior 
in society at large. For a long time the English college persisted in barring women from sitting its examinations, twice voting against the proposal. However, in 1908 the college finally admitted woman to all its examinations. Four years later, Lily Fanny Pain became the first female to gain its LDS, seventeen years after Lilian Murray (later Lindsay) qualified from the Edinburgh college.

\section{THE FIGHT FOR REGISTRATION}

By the late 19th century dentistry was well on the way to becoming a recognised profession, but it needed another push. When the LDS was established it was hoped that holders of this qualification would be able to register it in the nedical Register, albeit in a separate section. Unfortunately it was not allowed. Those people who strove for establishment of the LDS knew they had another fight on their hands. So they fought for the establishment of a Dentists Register, which was eventually established by virtue of the 1878 Dentists Act. They hoped it would restrict dental practice to qualified and registered dentists. They failed in this aspiration, only succeeding in preventing unqualified practitioners from calling themselves dental surgeons or qualified dentists. When the first Dentists Register was published in 1879, 483 people (9.1\% of those registered) had an LDS. John Tomes was the first person whose name was inscribed in the register and he became the second dental knight, in 1886 , three years after Saunders.

Little did the first holders of the LDS realise how their qualification would provide a sound basis for many later exciting developments in the universities as well as at all the royal colleges.

Thanks are due to Sarah Pearson, Curator of the Hunterian Museum at the Royal College of Surgeons of England; Louise King, Assistant Archivist, RCS England; Rachel Bairsto, Head of the BDA Museum Services and Melanie Parker, Education Officer, BDA Museum. Thanks are also due to Librarians and Archivists at the Royal Society of Medicine, BDA and the Wellcome Collection. The General Dental Council should be acknowledged for data and finally thanks to the BDA Museum for permission to reproduce the photographs and permission to reproduce the Rowlandson picture.

1. Dobson J, Milnes-Walker R. Barbers and barbersurgeons of London. London: Blackwell Scientific Publications, 1979.

2. Richards N D. The dental profession in the 1860s. In F N L Poynter (ed) Medicine and Science in the 1860s. pp 267-288. London: Wellcome Institute in the History of Medicine, 1968.

3. Hill A. The history of the reform movement in the dental profession in Great Britain during the last twenty years. London: Trübner, 1877.

4. Waite G. Appeal to Parliament, the medical profession and the public on the present state of dental surgery. London, 1841.

5. Rymer S L. Letter to the editor. Lancet 1855; II: 181.

6. Spencer E M. Notes on the history of dental dispensaries. Med Hist 1982; 26: 47-66.

7 Smith E and Cottell B. A history of the Royal Dental Hospital of London and School of Dental Surgery 1858-1985. London: The Athlone Press, 1997.

8. Donaldson J A. The National Dental Hospital, 1859 1914. London: British Dental Journal Publications, 1992.

9. Bishop M, Parker M. Sir John Tomes F R S, Fellows of the Royal Society and dental reform in the nineteenth century. Notes Records R Soc Lond 2010; 64: 401-416.

10. Royal College of Surgeons of England. Minutes of the Dental Board. 1 March 1860.

11 Royal College of Surgeons of England. Minutes of the Dental Board. 8 March 1860.

12. Royal College of Surgeons of England, Board of Examiners in Dental Surgery, Minutes. 13 March 1860

13. Pugh M. Dentists strive for recognition. The Apothecary 2010; 31-33. 